\title{
Advances in the development of a noninvasive embryo model for the evaluation of the quality of cloned embryos subjected to different treatments
}

\author{
Ricardo Felmer* \\ Laboratorio de Biotecnología Animal \\ INIA-Carillanca, Casilla 58-D \\ Temuco, Chile \\ Tel: 5645 215706. Ext. 311 \\ Fax: 5645216112 \\ E-mail: rfelmer@inia.cl \\ María Elena Arias \\ Laboratorio de Biotecnología Animal \\ INIA-Carillanca. Casilla 58-D \\ Temuco, Chile \\ Tel: 5645 215706. Ext. 293 \\ Fax: 5645216112 \\ E-mail:marias@inia.cl
}

Financial support: This research was partially supported by grants from FONDEF D03I1074 and FONDECYT 1080216.

Keywords: bovine embryos, HcRed, nuclear transfer.

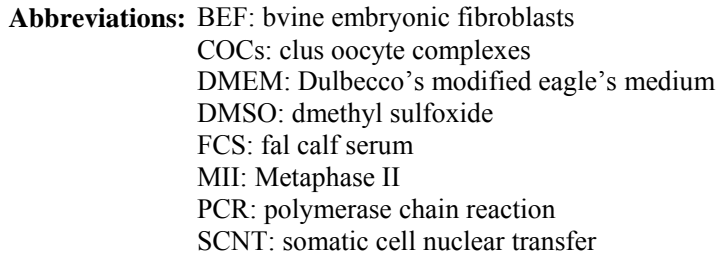

Total number of cells in cloned embryos is generally lower than that of in vivo derived embryos and in bovines cell allocation at the blastocyst stage, has been observed to be affected in a large proportion of cloned embryos. The current embryo staining procedures are toxic for mammalian cells and thus can not be used to determine the developmental potential of a stained embryo. Therefore, in the present study we sought to assess the feasibility to develop a noninvasive embryo model that would be suitable for the evaluation of cloned embryos subjected to different nuclear transfer and embryo culture procedures. For doing this, we stably transfected a bovine embryonic fibroblast cell line and generated a number of clones that constitutively expressed a red fluorescent protein (HcRed) in the nuclear compartment of the cell. Those clones with normal chromosomal content were further used as nuclear donor in nuclear transfer procedures (SCNT) to generate transgenic cloned embryos. These embryos expressed the red fluorescent protein in each blastomere, allowing their in vivo evaluation during development, thus demonstrating the potential of this model as a noninvasive tool for the assessment of the quality of cloned embryos.

Cloning by SCNT has gained great interest between researchers due to the potential application of this technology in different areas including animal griculture, biotechnology, biomedicine, preservation of endangered species and basic research (Cibelli et al. 1998; Wells et al. 1999; Lanza et al. 2000; Keefer, 2004). The success of the technology originally described by Wilmut and colleges (Wilmut et al. 1997) has been replicated since then to clone the most important agricultural and domestic species (Cibelli et al. 1998; Wakayama et al. 1998; Baguisi et al. 1999; Polejaeva and Campbell, 2000; Chesne et al. 2002; Shin et al. 2002; Galli et al. 2003; Zhou et al. 2003; Li et al. 2006). However, in spite of the success in these species, the efficiency of the technology is still very low, with a success rate reported no greater than 4\% (Wilmut et al. 1997; Wakayama et al. 1998; Miyoshi et al. 2001). Furthermore, a high abortion rate and mortality during pregnancy are commonly reported (Hill et al. 2000). There are a number of factors that may contribute to the low efficiency rate of

*Corresponding author 

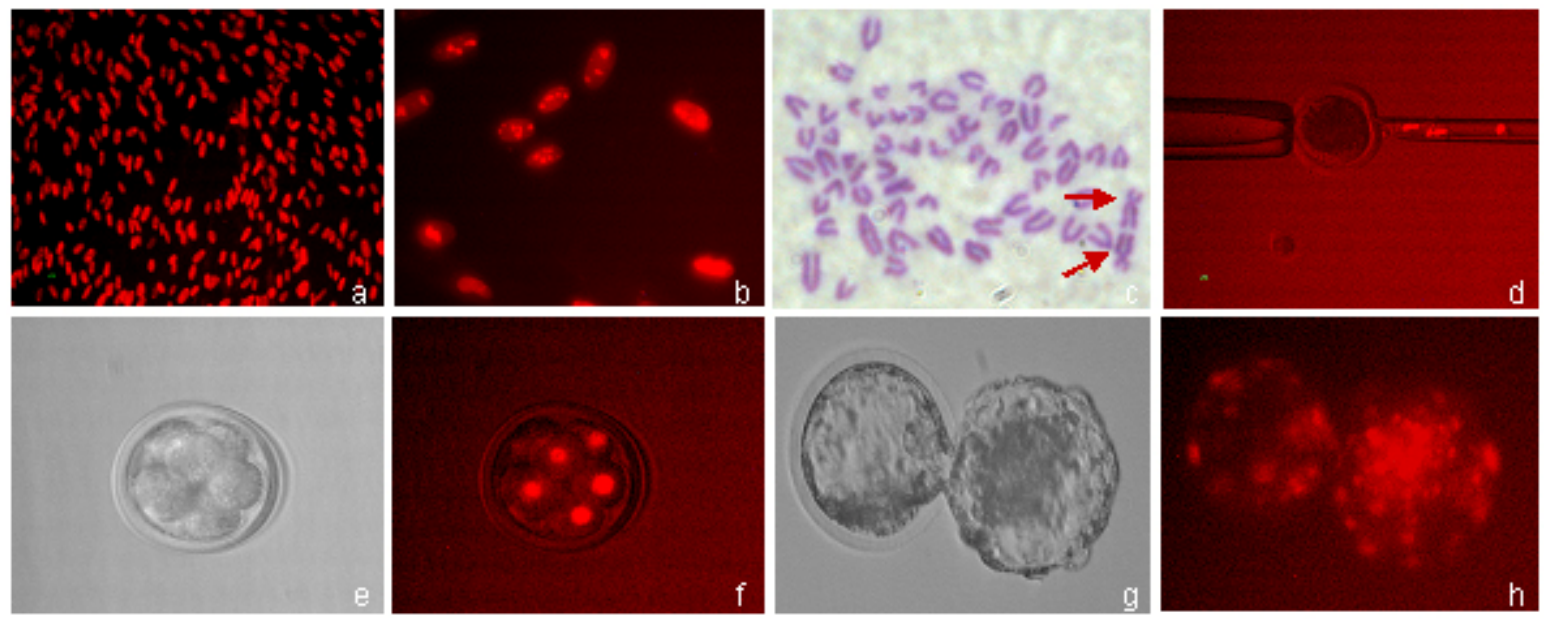

Figure 1. Developmental assessment of transgenic cloned embryos generated with bovine embryonic fibroblasts (BEF) expressing HcRed.

a) Transfected BEF expressing HcRed (20x);

b) Expression of the red fluorescent protein in the cellular nuclei (40x);

c) Karyotyping analysis of metaphase spreads of transfected BEF, with sexual chromosomes highlighted (arrows);

d) Nuclear transfer procedure with cells expressing HcRed;

e-h) Developmental assessment of transgenic cloned embryo expressing the red fluorescent protein in the blastomeres (HcRed).

this technology, including the cell cycle co-ordination between the donor nucleus and recipient oocyte, artificial activation procedure, in vitro culture conditions for the reconstructed embryos and an inadequate nuclear reprogramming, some of which may have a direct impact on the end quality of the generated embryo and the survival after transfer to recipients.

It has been reported that the total number of cells in cloned embryos is generally lower than that of in vivo derived embryos (Koo et al. 2000; Chesne et al. 2002; Chung et al. 2002; Koo et al. 2002). Furthermore, in bovines not only the total number of cells but also cell allocation at the blastocyst stage is affected in a large proportion of cloned embryos, with some observations of a reduced trophoblast to total cell number ratio compared to IVF and in vivo derived embryos (Koo et al. 2002). This lower number of trophoblast cells, might be responsible for the insufficient formation of the placenta observed in some nuclear transfer pregnancies. Therefore, it seems that correct allocation of cells at the blastocyst stage is necessary for a proper embryonic and fetal development. One of the limitations to assess the cell allocation and total number of cells in the embryos is that the procedure of staining is toxic for mammalian cells, thus preventing its application to determine the developmental potential of a stained embryo. Therefore, the objective of the present study was to assess the feasibility to develop a noninvasive embryo model that would be suitable for the evaluation of cloned embryos subjected to different nuclear transfer and embryo culture procedures. This will allow to determine developmental abnormalities in the embryos as result of an inadequate nuclear reprogramming or as direct consequence of sub optimal culture conditions, making possible to assess the developmental potential of these embryos postimplantation.

\section{MATERIALS AND METHODS}

\section{Preparation of donor cell}

A primary cell line of bovine embryonic fibroblasts (BEF) was isolated from a 50 days old fetus. Differentiated tissues were removed and soft tissue were cut into small pieces and the explants cultured in Dulbecco's Modified Eagle's Medium (DMEM, Gibco)supplemented with $10 \%$ fetal calf serum (FCS, HyClone), 1\% (v:v) penicillin/streptomycin (Gibco) at $37^{\circ} \mathrm{C}$ in a humidified atmosphere of $5 \% \mathrm{CO}_{2}$. After 10 days in culture, the explants were removed, and the cells were harvested by trypsinization, counted, and seeded in $75 \mathrm{~cm}^{2}$ tissue culture flasks. When the cells reached confluency, they were collected by trypsinization and frozen in DMEM supplemented with 10\% FCS and 10\% dimethyl sulfoxide (DMSO, Sigma).

\section{DNA preparation, transfection and selection of clonal cell lines}

The plasmid directing red fluorescence protein was a version of $\mathrm{pHcRed1-nuc} \mathrm{(Clontech),} \mathrm{kindly} \mathrm{provided} \mathrm{by} \mathrm{Dr.}$ Pablo Ross. BEF were transfected with linearized plasmidDNA using Lipofectamine according to the manufacturer's instructions (Invitrogen). Briefly, 2 × $10^{5}$ cells were seeded in a $35-\mathrm{mm}$ culture plate 1 day before transfection. Cells were transfected with $2 \mu \mathrm{g}$ plasmid DNA using $10 \mu \mathrm{l}$ of Lipofectamine. After transfection, the cells were selected with $800 \mu \mathrm{g} / \mathrm{ml}$ Geneticin (G418, HyClone) for 7-10 days. Single colonies were isolated by ring cloning and further expanded in the presence of $400 \mu \mathrm{g} / \mathrm{ml} \mathrm{G} 418$. When 
confluence was achieved, cells were passaged to 6-well plates and then to $100-\mathrm{mm}$ plates. A portion of the cells were used for DNA isolation and confirmation of construct integration by PCR, andchromosome analysis. The remaining cells were frozen in DMEM supplemented with $10 \%$ FCS and $10 \%(\mathrm{v}: \mathrm{v})$ DMSO.

\section{Chromosome analysis}

For cytogenetic analysis, each clone was grown in DMEM media containing $10 \% \mathrm{FCS}$ for $48 \mathrm{hrs}$ at $39^{\circ} \mathrm{C}$. When the cells reach confluency, they were incubated in growth media supplemented with $0.5 \mu \mathrm{g} / \mathrm{ml}$ KaryoMax (GIBCO) for $5-6 \mathrm{hrs}$ at $39^{\circ} \mathrm{C}$. Then, cells were trypsinized and treated with hypotonic solution of $0.9 \%$ Sodium citrate for $25 \mathrm{~min}$ at $39^{\circ} \mathrm{C}$, fixed in methanol:acetic acid (3:1), and drops of cell suspension were spread on clean microscopic slides. The chromosomes were stained with $5 \%$ Giemsa for $10 \mathrm{~min}$ and examined at $\mathrm{x} 1.000$ magnification under oil to determine the modal chromosome number.

\section{Oocyte collection and maturation}

Bovine ovaries were colleted from a local slaughterhouse and transported to the lab in physiological saline solution. Antral follicles of 2 to $8 \mathrm{~mm}$ in diameter were aspirated using an 18-gauge needle and collected into a $50 \mathrm{ml}$ conical tube. Cumulus oocyte complexes (COCs), surrounded by more than four compact layers of cells and with evenly granulated cytoplasm were selected for maturation, that was

Table 1. Evaluation of transgenic cell lines expressing the red fluorescent protein (HcRed).

\begin{tabular}{|c|c|c|c|c|}
\hline Cell Lines & $\begin{array}{l}\text { Level of HcRed } \\
\text { expression } \\
\text { in cells }\end{array}$ & $\begin{array}{l}\text { Karyotyping } \\
\text { analysis }\end{array}$ & $\begin{array}{c}\text { Morfology/No } \\
\text { Passages }\end{array}$ & $\begin{array}{c}\text { Cloned } \\
\text { Blastocyst/ } \\
\text { Fluorescence }\end{array}$ \\
\hline clone 1 & Medium & $2 n=60, x x$ & Normal/>10 & Yes/Low \\
\hline clone 2 & Low & $2 n=60, x x$ & Normal/>10 & Yes/Low \\
\hline clone 3 & N. Detec. & N.D. & N.D. & N.D. \\
\hline clone 4 & N. Detec. & N.D. & N.D. & N.D. \\
\hline clone 5 & N. Detec. & N.D. & N.D. & N.D. \\
\hline clone 6 & Low & $2 n=58, x x$ & Senescent $/<5$ & No \\
\hline clone 7 & N. Detec. & N.D. & N.D. & N.D. \\
\hline clone 8 & Low & $2 n=60, x x$ & Normal/>10 & Yes/N. Detec. \\
\hline clone 9 & High & $2 n=60, x x$ & Senescent $/<5$ & No \\
\hline clone 10 & N. Detec. & N.D. & N.D. & N.D. \\
\hline clone 11 & N. Detec. & N.D. & N.D. & N.D. \\
\hline clone 12 & N. Detec. & N.D. & N.D. & N.D. \\
\hline clone 13 & N. Detec. & N.D. & N.D. & N.D. \\
\hline clone 14 & N. Detec. & N.D. & N.D. & N.D. \\
\hline clone 15 & N. Detec. & N.D. & N.D. & N.D. \\
\hline
\end{tabular}

Clones selected for later analysis; N. Detec.: Non Detected; N.D.: Non Determined. 
carried out in Medium 199 supplemented with $10 \%$ FCS (HyClone), $1 \mu \mathrm{g} / \mathrm{ml}$ of FSH (Sioux Biochem), $1 \mu \mathrm{g} / \mathrm{ml}$ of LH (Sioux Biochem), $1 \mu \mathrm{g} / \mathrm{ml} \mathrm{17b-estradiol,} 2.3 \mathrm{mM}$ of sodium pyruvate, and $25 \mu \mathrm{g} / \mathrm{ml}$ of gentamicin sulphate (Gibco) at $37^{\circ} \mathrm{C}$ in a humidified atmosphere of $5 \% \mathrm{CO}_{2}$ in air.

\section{Nuclear transfer}

After maturation, oocytes were vortexed to remove expanded cumulus cells and stained using Hoechst 33342 $(5 \mu \mathrm{g} / \mathrm{ml})$ for 10 minutes to aid the visualization of the DNA (chromatin). Oocytes were enucleated with a 15 $\mu \mathrm{m}$ (internal diameter) glass pipette by aspirating the MII plate in a smallvolume of surrounding cytoplasm. Prior to nuclear transfer, donor cells were grown to confluency for 5 days. These cells (one per oocyte) were microsurgically placed into the perivitelline space evacuated during enucleation, ensuring intimate contact between the donor cell and the recipient oocyte. After transfer, the cellcytoplast complexes were induced to fuse in sorbitol media with a single DC pulse of 170 volts $/ \mathrm{mm}$ and $15 \mu \mathrm{sec}$ by an Electrocell Manipulator 830 (BTX). Immediately after electric pulse delivery, the oocytes were activated with 5 $\mu \mathrm{M}$ Ionomicin for $5 \mathrm{~min}$ followed by incubation in KSOM media containing cycloheximide $(10 \mu \mathrm{g} / \mathrm{ml}$ for $5 \mathrm{hrs})$. After activation, the NT units were cultured in $25 \mathrm{ml}$ drops of $\mathrm{KSOM}$ media under mineral oil at $38.5^{\circ} \mathrm{C}$ and at $5 \% \mathrm{CO}_{2}$, $5 \% \mathrm{O}_{2}, 90 \% \mathrm{~N}_{2}$. On day 3 ( $\mathrm{NT}=$ day 0 ), the embryos were transferred to $\mathrm{KSOM}+5 \% \mathrm{FCS}$ and cultured under the same conditions until day 7 , when blastocyst rate and marker fluorescence were assayed.

\section{RESULTS AND DISCUSSION}

The present study demonstrated the feasibility of a primary cell line derived from bovine embryonic fibroblasts of being stably transfected with the marker gene pHcRed1-nuc and confirmed the suitability of these cells as nuclear donors for the generation of transgenic cloned embryos. Epifluorescence microscopy allowed to confirm expression of the red fluorescent protein in the nuclear cell compartment both in different clonal lines (Figure 1a; Figure $1 \mathrm{~b}$ ) and in the blastomeres of embryos generated with these cells used as nuclear donors (Figure 1d; Figure 1h). We generated 15 G418-resitant cell lines that were positive by PCR analysis to the marker gene (data not shown), 5 of which expressed the red fluorescent protein at different levels (Figure $1 \mathrm{~b}$ and Table 1). The karyotyping analysis of clones expressing HcRed, showed a normal chromosome complement of $2 n=60 ; X X$, in 4 out of 5 clones analyzed (Figure 1c and Table 1), while one of the clones (clone 6) had a decreased in one pair of somatic chromosomes, which may correlate with the premature senescence previously observed in this cell line (Table 1).

The evaluation of these cells (passage 5) as nuclear donors in SCNT, allowed the generation of transgenic cloned embryos with 3 out of 5 cell lines analyzed (Table 1). Two of the cell lines had previously shown a premature senescence in cellular growth and maintenance assessments, which may explain the inability of these cells to generate transgenic cloned blastocysts. However, with the other lines it was possible to generate transgenic cloned embryos that expressed HcRed in each blastomere, making possible their evaluation in vivo during the different stages of the embryonic development, including the blastocyst stage, the stage in which the embryos are suitable for transfer to synchronized recipients (Figure 1e; Figure 1h). Nevertheless, the low level of expression observed in these embryos, concomitant with the expression pattern observed in the cells prior to nuclear transfer, did not allow the accurate count of the total number of cells at the blastocyst stage, preventing in this way a quantitative evaluation of the quality of these embryos after different culture conditions. However, the generated model allowed the qualitative assessment of cloned embryos, providing a valuable tool for the selection of good quality embryos based not only in the general morphological evaluation, but also in the rough estimate of the total number of cells, information that could be useful in embryo transfer procedures, to avoid the transfer of embryos with low quality and/or low post implantation potential. Furthermore, this model may have a great potential to improve nuclear transfer efficiency, especially in bovines where the total number of cells and cell allocation at the blastocyst stage have been reported to be lower than those of in vivo derived embryos, attributing this as the main cause of the placentation problems observed in some nuclear transfer pregnancies (Koo et al. 2000; Chung et al. 2002; Koo et al. 2002), observations that are difficult to confirm because they invariably involved the destruction of the embryo and/or the staining with embryo toxic substances.

\section{CONCLUDING REMARKS}

The generated model demonstrated its potential as a noninvasive tool for the assessment of the end quality of cloned embryos. Although for an optimal application of this model, it is necessary to generate a cloning cell line that would ensure high level of expression of HcRed at each blastomeres of the developing embryo. In these conditions, the model could allow to identify structural abnormalities in the developing embryo as result of an inadequate nuclear reprogramming or as direct consequence of sub optimal culture conditions, making possible to assess the developmental potential of these embryos postimplantation. Further refinement of this model include the double expression of reporter genes to the trophoectoderm and inner cell mass cells, which would allow the assessment of cell allocation in the embryo as well as total number of cells, experiments that are under way.

\section{ACKNOWLEDGMENTS}

The provision of ovaries by our local Slaughterhouse (Frigorífico Temuco) and technical support by Gastón Muñoz and Horacio Floody are gratefully acknowledged. 


\section{REFERENCES}

BAGUISI, A.; BEHBOODI, E.; MELICAN, D.; POLLOCK, J.S.; DESTREMPES, M.M.; CAMMUSO, C.; WILLIAMS, J.L.; NIMS, S.D.; PORTER, C.A.; MIDURA, P.; PALACIOS, M.J.; AYRES, S.L.; DENNISTON, R.S.; HAYES M.L.; ZIOMEK, C.A.; MEADE, H.M.; GODKE, R.A.; GAVIN, W.G.; OVERSTROM, E.W. and ECHELARD, Y. Production of goats by somatic cell nuclear transfer. Nature Biotechnology, May 1999, vol. 17, no. 5 , p. $456-461$.

CHESNE, P.; ADENOT, P.G.; VIGLIETTA, C.; BARATTE, M.; BOULANGER, L. and RENARD, J.P. Cloned rabbits produced by nuclear transfer from adult somatic cells. Nature Biotechnology, April 2002, vol. 20, no. 4, p. 366-369.

CHUNG, Y.G.; MANN, M.R.; BARTOLOMEI, M.S. and LATHAM, K.E. Nuclear-cytoplasmic "tug of war" during cloning: effects of somatic cell nuclei on culture medium preferences of preimplantation cloned mouse embryos. Biology of Reproduction, April 2002, vol. 66, no. 4, p. 1178-1184.

CIBELLI, J.B.; STICE, S.L.; GOLUEKE, P.J.; KANE, J.J.; JERRY, J.; BLACKWELL, C.; PONCE DE LEON, F.A. and ROBL, J.M. Cloned transgenic calves produced from nonquiescent fetal fibroblasts. Science, May 1998, vol. 280, no. 5367 , p. $1256-1258$.

GALLI, C.; LAGUTINA, I. and LAZZARI, G. Introduction to cloning by nuclear transplantation. Cloning and Stem Cells, 2003, vol. 5, no. 4, p. 223-232.

HILL, J.R.; BURGHARDT, R.C.; JONES, K.; LONG, C.R.; LOONEY, C.R.; SHIN, T.; SPENCER, T.E.; THOMPSON, J.A.; WINGER, Q.A. and WESTHUSIN, M.E. Evidence for placental abnormality as the major cause of mortality in first-trimester somatic cell cloned bovine fetuses. Biology of Reproduction, December 2000, vol. 63, no. 6, p. 1787-1794.

KEEFER, C.L. Production of bioproducts through the use of transgenic animal models. Animal Reproduction Science, July 2004, vol. 82, p. 5-12.

KOO, D.B.; KANG, Y.K.; CHOI, Y.H.; PARK, J.S.; HAN, S.K.; PARK, I.Y.; KIM, S.U.; LEE, K.K.; SON, D.S.; CHANG, W.K. and HAN, Y.M. In vitro development of reconstructed porcine oocytes after somatic cell nuclear transfer. Biology of Reproduction, October 2000, vol. 63, no. 4, p. 986-992.

KOO, D.B.; KANG, Y.K.; CHOI, Y.H.; PARK, J.S.; KIM, H.N.; OH, K.B.; SON, D.S.; PARK, H.; LEE, K.K. and HAN, Y.M. Aberrant allocations of inner cell mass and trophectoderm cells in bovine nuclear transfer blastocysts. Biology of Reproduction, August 2002, vol. 67, no. 2, p. 487-492.
LANZA, R.P.; DRESSER, B.L. and DAMIANI, P. Cloning Noah's Ark. Scientific American, 2000, vol. 283, p. 84-89.

LI, Z.; SUN, X.; CHEN, J.; LIU, X.; WISELY, S.M.; ZHOU, Q.; RENARD, J.P.; LENO, G.H. and ENGELHARDT, J.F. Cloned ferrets produced by somatic cell nuclear transfer. Developmental Biology, May 2006, vol. 293, no. 2, p. 439-448.

MIYOSHI, K., RZUCIDLO, S.J.; GIBBONS, J.R.; ARAT, S. and STICE, S.L. Development of porcine embryos reconstituted with somatic cells and enucleated metaphase I and II oocytes matured in a protein-free medium. BMC Developmental Biology, July 2001, vol. 1, no. 12.

POLEJAEVA, I.A. and CAMPBELL, K.H. New advances in somatic cell nuclear transfer: application in transgenesis. Theriogenology, January 2000, vol. 53, no. 1, p. 117-126.

SHIN, T.; KRAEMER, D.; PRYOR, J.; LIU, L.; RUGILA, J.; HOWE, L.; BUCK, S.; MURPHY, K.; LYONS, L. and WESTHUSIN, M. A cat cloned by nuclear transplantation. Nature, February 2002, vol. 415, no. 6874, p. 859.

WAKAYAMA, T.; PERRY, A.C.; ZUCCOTTI, M.; JOHNSON, K.R. and YANAGIMACHI, R. Full-term development of mice from enucleated oocytes injected with cumulus cell nuclei. Nature, July 1998, vol. 394, no. 6691, p. 369-374.

WELLS, D.N.; MISICA, P.M. and TERVIT, H.R. Production of cloned calves following nuclear transfer with cultured adult mural granulosa cells. Biology of Reproduction, April 1999, vol. 60, no. 4, p. 996-1005.

WILMUT, I.; SCHNIEKE, A.E.; MCWHIR, J.; KIND, A.J. and CAMPBELL, K.H. Viable offspring derived from fetal and adult mammalian cells. Nature, February 1997, vol. 385 , no. 6619 , p. $810-813$.

ZHOU, Q.; RENARD, J.P.; LE FRIEC, G.; BROCHARD, V.; BEAUJEAN, N.; CHERIFI, Y.; FRAICHARD, A. and COZZI, J. Generation of fertile cloned rats by regulating oocyte activation. Science, November 2003, vol. 302, no. 5648, p. 1179. 